\title{
La piedra como material de construcción: durabilidad, deterioro y conservación
}

\author{
Rock as a construction material: durability, \\ deterioration and conservation
}

Fecha de recepción: 21-III-91

ROSA M." ESBERT, MODESTO MONTOTO y JORGE ORDAZ

Departamento de Geología, Grupo de Petrofísica.

Universidad de Oviedo. España

\section{RESUMEN}

Se compendian los distintos aspectos relacionados con el deterioro y la conservación de la piedra utilizada como material de edificación. Se revisan las características petrográficas y propiedades físicas que controlan la durabilidad de los materiales pétreos, resaltando la importancia de los espacios vacíos y de aquellas propiedades más directamente relacionadas con la captación y transferencia de humedad por el interior de la piedra. En cuanto a los procesos de deterioro se destaca el papel del agua, de las sales solubles y de los contaminantes atmosféricos en los diversos mecanismos de alteración desarrollados en la piedra de edificación. Finalmente se plantean las diversas fases relacionadas con la conservación de la piedra, y se revisan los métodos y productos más empleados en la actualidad para tal fin.

\begin{abstract}
$S U M M A R Y$
The different aspects related to the deterioration and conservation of stone, used as a construction material, are reviewed in this article. The petrographical characteristics and physical properties which control the durability of stone material are stated. The importance of the voids and the properties more directly linked to the up-taking and transfer of humidity through the stone are pointed out. Regarding to the deterioration processes, the role of water, soluble salts and atmospheric pollutants upon the different alteration mechanisms of the building stones is emphasized. Finally, the steps related to the stone conservation, and the methods and products more currently employed to that aim are revised.
\end{abstract}

\section{INTRODUCCION}

Desde la antigüedad la piedra ha sido uno de los materiales preferentemente utilizados en edificación y escultura, sobre todo en aquellas obras de especial significación histórica, con las que se ha pretendido dar testimonio de la época. En edificación la piedra se ha utilizado habitualmente en forma de sillares, y más recientemente, con carácter ornamental, en forma de losetas de revestimiento.

Aunque se trate de un material considerado como resistente a la intemperie, casi nunca se encuentra en equilibrio con el ambiente en el cual se halla emplazado, lo que provoca modificaciones en sus características iniciales. Estas modificaciones, dentro de ciertos límites,

\section{INTRODUCTION}

Since antiquity, stone has been one of the preferred materials for use in building and sculpture, particularly for those works of special historical importance designed to be a memorial to their age. In building, stone has usually been employed in the form of blocks and, more recently, as ornamental rock cladding or facing.

Although rock materials are normally considered to be resistant to weathering, almost none can be found which are in equilibrium with the environment in which they are placed; this leads to changes in their original properties. These changes, within certain limits, can often be 
pueden ser consideradas incluso positivas; la piedra cambia ligeramente su aspecto, y adquiere una pátina que le confiere un cierto valor estético y que puede relentizar la acción de los agentes de alteración. Sin embargo cuando el ambiente es más agresivo la piedra sufre modificaciones importantes que se traducen en un progresivo deterioro, el cual va ligado, en muchos casos, a una grave merma de sus cualidades estéticas.

Es pues en estas condiciones cuando adquieren especial importancia los estudios de la durabilidad del material pétreo, de los procesos de deterioro, de los métodos y productos de conservación aplicados a la piedra y la experimentación sobre el comportamiento futuro de los sistemas piedratratamiento. Estos aspectos son los que se sintetizan en este trabajo

\section{CARACTERIZACION DE MATERIALES PETREOS Y PARAMETROS INTRINSECOS QUE CONTROLAN SU DURABILIDAD}

Al estudiar los materiales rocosos destaca, en primer lugar, la presencia de discontinuidades y anisotropías; su naturaleza, por lo general, polifásica; la falta de homogeneidad, etc.; aspectos todos ellos que, si por una parte les asemejan al hormigón, por otra les aparta de los materiales industriales más utilizados y estudiados. Esto dificulta la extrapolación de los conocimientos en Ciencia de Materiales al de las rocas, y más concretamente al de las interpretaciones petrofísicas requeridas en los estudios alterológicos.

Desde el punto de vista petrofísico los componentes petrográficos que definen las características de las rocas y permiten interpretar sus propiedades físicas son, en esencia, la textura y la mineralogía (Montoto, 1983). En temas alterológicos y de durabilidad de materiales pétreos, debe, en especial, enfatizarse la importancia de los espacios vacíos como componentes texturales, analizando en detalle su configuración tridimensional o sistema poroso. Dicho análisis permite conocer el grado de conectividad de las fisuras y de los canales porosos, el radio de acceso de los poros, su localización en relación con los componentes minerales, etc.

Todos estos aspectos condicionan la circulación de fluidos - agua principalmente - por el seno de la roca, y por consiguiente toda una serie de propiedades hídricas que, a su vez, condicionan los procesos de alteración y de degradación física y química de la roca.

Por ejemplo, en las piedras de la Catedral de Oviedo (calizas y dolomías) se reconoce una clara relación entre la alteración química de la piedra, su tamaño medio de grano y la porosidad advantageous; a stone can mellow in appearance and acquire surface qualities which confer certain aesthetic value and slow down the action of weathering agents. In more aggressive environments, however, building stone can suffer more severe changes that can develop into a progressive deterioration coupled with a serious loss of aesthetic qualities.

It is under these conditions that the study of the durability of rock materials, the deterioration processes, the methods and products of conservation, and the experimental work on the future behaviour of systems stone-treatment, acquire special importance. These aspects are reviewed in the article.

\section{CHARACTERISATION OF ROCK MATERIALS AND THE INTRINSIC PARAMETERS WHICH CONTROL DURABILITY}

In the study of rock materials it must be emphasised, at the outset, that the presence of discontinuities and anisotropies; the normally polyphase nature of rocks; and their inhomogeneity, make rocks, though similar to concrete in some respects, very unlike other commonly used and studied industrial materials. It is, therefore, very difficult to apply the principles of Materials Science to rocks, especially where the petrophysical interpretation of the results of alteration studies is concerned.

From the petrophysical point of view, the essential petrographical components that characterise a rock and allow interpretation of its physical properties are texture and mineralogy (Montoto, 1983). With regard to the deterioration and durability of rock materials, the importance of voids as textural components must be emphasised, and the three dimensional form of the pore system must be analyzed. This analysis provides an understanding of the degree of connectivity of microfissures and pore channels, the pore throat radii, the location of pores in relation to mineral components, etc.

These characteristics control the circulation of fluids (principally water) through the rock and, consequently, a whole series of hydraulic properties which, in turn, control the processes of alteration and the physical and chemical decay of the rock.

In the building stones of Oviedo Cathedral (limestones and dolomites), for example, a clear relation can be recognised between the chemical alteration of the rock, the mean grain size, and 
intergranular asociada. Así, la dolomía micrítica de Laspra, microporosa, con multitud de pequeños poros, con radios de acceso inferiores a $0,004 \mu \mathrm{m}$, muestra un avanzado deterioro de tipo químico. Sin embargo, otro tipo de piedra de la misma catedral, también carbonatada (caliza de Piedramuelle), con granos y poros de mayor tamaño, aunque con una porosidad menor, está menos deteriorada.

Otras características textuales a resaltar son las que relacionan espacialmente los componentes de la roca, como las uniones intergranulares y la naturaleza del cemento o de la matriz; la presencia de posibles anisotropías texturales o granulométricas, etc. Las uniones intergranulares condicionan, en gran medida, la aplicabilidad y durabilidad de las rocas, por lo que incluso se han tomado como criterio clasificatorio de interés petrofísico, dividiéndolas en cristalinas y cementadas. Ambos tipos presentan propiedades físicas muy diferentes, en especial las rocas cementadas, en las que, además de exhibir una gran dispersión de valores, son también más alterables.

Para la observación, cuantificación y cartografiado de los mencionados componentes petrográficos existen hoy en día muy variadas técnicas microscópicas (ópticas, electrónicas, acústicas), de proceso digital de imágenes, etc; que, en conjunto, permiten realizar mejores interpretaciones petrofísicas y también predicciones sobre su comportamiento físico futuro.

Por otra parte, las propiedades físicas de las diferentes variedades pétreas presentes en una edificación deben ser valoradas e interpretadas petrográficamente, como fundamento imprescindible para la posterior interpretación de las diversas patologías alterológicas existentes. Las más significativas de dichas propiedades se relacionan, por ejemplo, en Esbert y Ordaz, 1985; Esbert et al. 1989. Las normas y recomendaciones más utilizadas para su determinación suelen ser: ISRM (International Society for Rock Mechanics); CNR-ICR (Centro di Studio sulle Cause di Diperimento e sui Metodi de Conservazione delle Opere d'Arte - Istituto Centrale del Restauro), RILEM (Reunión Internacional de Laboratorios de Ensayos de Materiales), ASTM, DIN, BS y UNE. A continuación se agrupan y mencionan dichas propiedades y el correspondiente método de ensayo sugerido para su determinación.

a) Propiedades que caracterizan el aspecto y la constitución física de los materiales rocosos: Color ("Rock-Color Chart", Goddard et al., 1979). Densidad de los granos minerales; densidad aparente de la roca seca; porosidad (ISRM, 1981). Mediante técnicas de porosimetría de inyección de mercurio puede the associated intergranular porosity. Thus, the micritic dolomite of Laspra, which is microporous, with many small pores with pore throat radii of less than $0.004 \mu \mathrm{m}$, shows an advanced state of chemical alteration. Other carbonate rock of the same cathedral (Piedramuelle limestone), however, with coarser grains and larger pores, but a lower porosity, is less deteriorated.

Other important textural characteristics are those which relate the rock components spatially, such as the grain boundaries, the type of cement or matrix, the presence of textural or granulometric anisotropies, etc. The nature of grain boundaries controls the applicability and durability of building stone, rocks being classified petrophysically as either crystalline or cemented. Both rock types have very different physical properties, cemented rocks showing greater variation in the values of key parameters and suffering greater alteration.

For observation, quantification and mapping of the above mentioned petrographical components, there are today many different microscopy techniques (optical, electron, acoustic), digital image processing systems, etc; which used together, allow improved petrophysical interpretation and the prediction of future physical behaviour.

On the other hand, the physical properties of the different stone types present in a building must be evaluated and interpreted petrographically as an essential prerequisite for assessing the diverse alteration processes taking place. The most significant of these properties have been described, for example, in Esbert and Ordaz, 1985; and Esbert et al., 1989. The standards and recommendations most commonly employed tend to be: ISRM (International Society for Rock Mechanics); CNR-ICR (Centro di Studio sulle Cause di Diperimento e sui Metodi di Conservazione delle Opere d'Arte - Istituto Centrale del Restauro); RILEM (International Union of Testing and Research Laboratories for Materials and Structures), ASTM, DIN, BS and UNE. Each of the key rock properties and the corresponding method or standard test recommended for its determination are briefly described below:

a) Properties which characterise the appearance and physical nature of rock materials: Colour ("Rock Colour Chart", Goddard et al., 1979). Density of mineral grains. Apparent density of the dry rock. Porosity (ISRM, 1981). By means of mercury porosimetry injection techniques, an approximation to the pore system can be 
obtenerse una aproximación a la configuración del sistema poroso (e.g. Wardlaw y Taylor, 1976;

Alonso et al., 1987).

b) Propiedades que caracterizan la circulación de fluidos por el seno de la piedra (propiedades hídricas): Absorción y desorción de agua; velocidad de absorción y evaporación; succión capilar; permeabiliad al vapor de agua; expansión hídrica; etc. (CNR-ICR, 1985; ISRM, 1979).

c) Propiedades que caracterizan el comportamiento deformacional (resistencia a la compresión uniaxial, módulos de elasticidad, calor específico, expansión térmica, etc.) (ISRM 1981; UNE, 1985; ASTM, 1988).

En la Tabla i se recoge el valor de algunas de las propiedades físicas descritas, referidas a rocas utilizadas en el patrimonio arquitectónico de Oviedo.

El examen de los valores de la Tabla / permite constatar el hecho de que rocas de la misma naturaleza petrográfica (calizas de Laspra y Piedramuelle) o de naturaleza similar (dolomía de Laspra), pueden mostrar valores muy diferentes en propiedades físicas tan determinantes para su alterabilidad como son la porosidad comunicada, la absorción libre de agua y la succión capilar, entre otras. obtained (e. g. Wardlaw and Taylor, 1976; Alonso et al., 1987).

b) Properties which characterise the circulation of fluids through the pore system of the stone (hydraulic properties): Absorption and desorption of water; absorption and evaporation velocity; capiliary suction, permeability to water vapour; expansion due to water uptake, etc. (CNR-ICR, 1985; ISRM, 1979).

c) Properties which characterise the deformation behaviour (uniaxial compressive strength, elastic modulii, specific heat, thermal expansion, etc) (ISRM, 1981; UNE, 1985: ASTM, 1988).

The values of some of the physical properties described here, for rocks used in the architectural heritage of Oviedo, are presented in Table $I$.

Examination of the values presented in Table I confirms the fact that rocks of the same petrophysical nature (Laspra and Piedramuelle limestones) or of similar nature (Laspra dolomite) can show very different values of physical properties including the main controls of alterability (the interconnected porosity, free water absorption and capillary suction, among others).

TABLA 1 TABLE 1

Propiedades físicas de algunas rocas monumentales de Asturias (Physical properties of some monumental stones of Asturias)

\begin{tabular}{|c|c|c|c|c|}
\hline $\begin{array}{l}\text { Variedad rocosa } \\
\text { (Rock type) }\end{array}$ & $\begin{array}{c}\text { Densidad } \\
\rho \cdot \mathrm{Kg} / \mathrm{m}^{3} \\
(\text { Density } \\
\left.\rho \cdot \mathrm{Kg} / \mathrm{m}^{3}\right)\end{array}$ & $\begin{array}{c}\text { Porosidad } \\
\text { comunicada } n_{0} \% \\
\text { (Interconnected } \\
\text { porosity } n_{0} \% \text { ) }\end{array}$ & $\begin{array}{l}\text { Coeficiente } \\
\text { absorción } w_{\bullet} \% \\
\text { (Absorption } \\
\text { coeffficient } w_{,} \% \text { ) }\end{array}$ & $\begin{array}{c}\text { Coeficiente } \\
\text { capilaridad } \\
\mathrm{C} \mathrm{kg} / \mathrm{m}^{2} \cdot \mathrm{min}^{1 / 2} \\
(\text { Capillarity } \\
\text { coefficient } \\
\left.\mathrm{C} \mathrm{kg} / \mathrm{m}^{2} \cdot \mathrm{min}^{1 / 2}\right)\end{array}$ \\
\hline $\begin{array}{l}\text { Dolomía de Laspra } \\
\text { (blanca) } \\
\text { [Laspra dolomite } \\
\text { (white)] }\end{array}$ & 1930 & 28,5 & 15 & 34,5 \\
\hline $\begin{array}{l}\text { Caliza de Laspra } \\
\text { (rosa) } \\
\text { [Laspra limestone } \\
\text { (pink)] }\end{array}$ & 2600 & 1,8 & 0,7 & 0,3 \\
\hline $\begin{array}{l}\text { Caliza de } \\
\text { Piedramuelle } \\
\text { (Piedramivelle } \\
\text { limestone) }\end{array}$ & 2050 & 18,3 & 11,5 & 80 \\
\hline
\end{tabular}


Resulta, pues, evidente que es arriesgado generalizar y fijar modelos de comportamiento para los diversos grupos de rocas genéticamente establecidos (calizas, areniscas, mármoles, granitos, etc.), puesto que las propiedades físicas pueden variar de manera notoria. Para la interpretación correcta de las diversas patologías alterológicas es necesaria, en cada caso, la determinación de, por lo menos, las propiedades físicas básicas.

Esta consideración es también válida en el campo de la conservación de la piedra, para establecer las sugerencias de tratamiento, ya que la idoneidad de muchas procedimientos de conservación, bien sean de limpieza, consolidación o hidrofugación, vienen controlados, en gran medida, por dichas propiedades.

\section{DETERIORO}

Como ya se ha indicado, los materiales pétreos colocados en un edificio o monumento, y expuestos a condiciones a menudo agresivas, tienden a deteriorarse como consecuencia de la combinación de diversos procesos químicos, físicos y biológicos (e.g. Stambolov y Van Asperen de Boer, 1976; Torraca, 1982; Ordaz y Esbert, 1988). En líneas generales, los agentes que contribuyen en mayor medida al deterioro de las piedras de construcción son: la humedad, las sales solubles y los contaminantes atmosféricos.

\section{Agua}

El agua es, por sí misma, uno de los más importantes agentes de alteración, al tiempo que sirve de vehículo para las acciones deteriorantes de otros agentes. Los efectos o daños ocasionados por el agua (humedad) en sus diversas formas (vapor, líquido, hielo) son básicamente de dos tipos: químicos y físicos (mecánicos). En el primer caso, el agua interviene en los principales procesos químicos que afectan a las rocas (p. ej. disolución de carbonatos, hidrólisis de silicatos, reacciones de oxidaciónreducción, hidratación, etc) (Press y Siever, 1985, Winkler, 1987). En el segundo caso, cuando el agua retenida en los poros de las piedras se hiela aumenta su volumen (unas nueve veces) y, en consecuencia, ejerce sobre las paredes de los poros una presión que, tras repetidos ciclos de hielo-deshielo, puede llegar a originar importantes daños físicos en la piedra (Lautridou, 1988).

\section{Sales solubles}

A corto plazo las piedras de edificación suelen verse afectadas por la presencia de soluciones acuosas conteniendo sales solubles de diversa naturaleza (principalmente sulfatos, nitratos y
It is clear, therefore, that it is dangerous to generalise and devise fixed behaviour models for the diverse rock types used (limestones, sandstones, marbles, granites, etc.) given that the physical properties can vary as they clearly do. For the correct interpretation of the various alteration processes that occur, it is, therefore, necessary to determine for each case at least the fundamental physical properties.

The determination of key physical properties is also necesary in the field of stone conservation in order to establish recomendations for treatment, since the effectiveness of many conservation procedures, such as cleaning, consolidation or hydrofuging, is controlled to a large extent by these properties.

\section{DETERIORATION}

As already shown, rock materials situated in a building or monument, and exposed to frequently aggressive conditions, tend to deteriorate as a consequence of a combination of different chemical, physical and biological processes (e. $g$. Stambolov and Van Asperen de Boer, 1976; Torraca, 1982; Ordaz y Esbert, 1988). Generally, the principal agents of deterioration are: moisture, soluble salts and atmospheric pollutants.

\section{Water}

Water is, itself, one of the most important agents of alteration, and serves to facilitate the deteriorating action of other agents. The effects or damages caused by water (moisture) in its various forms (vapour, liquid, ice) are basically of two types: chemical and physical (mechanical). As a chemical agent, water participates in the principal processes that affect rocks (e. g. carbonate dissolution, hydrolysis of silicates, oxidationreduction reactions, hydration, etc.) (Press and Siever, 1985; Winkler, 1987). In terms of mechanical deterioration, the freezing of water held in the pores of building stones produces an increase in volume (about nine times). This exerts pressures on the pore walls which, after repeated freeze-thaw cycles, can cause remarkable physical damage to the stone (Lautridou, 1988).

\section{Soluble salts}

In the short term, building stones tend to be affected by the presence of aqueous solutions containing soluble salts of a diverse nature (principally sulphates, nitrates and chlorides of 
cloruros de calcio, sodio, potasio y magnesio) (Arnold y Zehnder, 1989). Estas sales pueden ser inherentes a la propia composición del material rocoso (p. ej. yeso en margas o calizas), o extrínsecas al mismo, ya procedan del suelo, de otros materiales de construcción (p. ej. morteros), de la interacción de minerales petrográficos con contaminantes atmosféricos o aerosoles marinos, o incluso derivadas de ciertos tratamientos de conservación. Las sales solubles dan lugar a eflorescencias, subflorescencias o criptoflorescencias al cristalizar en la superficie de la piedra, cerca de ella o en el interior de la misma. También suelen acumularse en el exterior en forma de costras o depósitos superficiales más o menos compactos. Además, las presiones ejercidas por la cristalización de sales solubles en el interior de poros y microfisuras de la piedra puede originar fenómenos disruptivos, sobre todo en aquellos materiales con mayor abundancia de microporos, dando lugar a diferentes formas de deterioro físico-químico (especialmente alveolización y arenización) (Valdeón et al., 1985; Binda y Baronio, 1987).

\section{Contaminantes atmosféricos}

La capacidad agresiva del agua, como agente de alteración química, puede verse sensiblemente incrementada por la presencia de subtancias contaminantes atmósfericas (Arnáiz y Vale, 1977; Benarie, 1985; Roswall, 1988). Entre los contaminantes que, en principio, pueden afectar, directa o indirectamente, la durabilidad de las piedras de construcción, se encuentran: óxidos de carbono, óxidos de nitrógeno y compuestos de azufre, gran parte de los cuales provienen de fuentes de inmisión antropogénicas (fundamentalmente de la combustión de combustibles fósiles). En presencia de humedad, estas substancias atacan los componentes de las piedras, dando lugar a la formación de sales solubles, cuyas efectos negativos han sido ya mencionados. En este sentido, son las áreas urbanas $\theta$ industriales, en las que mayores índices de contaminación se han alcanzado en las últimas décadas, donde el deterioro de los materiales pétreos se ha visto más acelerado, si bien los efectos de dichas substancias pueden extenderse también a las áreas rurales, a través de las lluvias ácidas.

\section{Otros agentes y mecanismos}

Además de los citados, las piedras se hallan expuestas también a otros mecanismos de deterioro. La acción biológica de ciertos organismos vivos (bacterias, algas, hongos, líquenes, etc), a partir, sobre todo, de los productos químicos generados por ellos (p. ej. ácidos orgánicos), coadyuva, en ocasiones, al deterioro físico-químico de los materiales rocosos calcium, sodium, potassium and magnesium) (Arnold and Zehnder, 1989). These salts can be part of the original composition of the rock material (e. g. gypsum in marls or limestones); or introduced from soil or other construction materials (e. g. mortars); or produced by the interaction of petrographic minerals with atmospheric pollutants or marine aerosols; or derived from certain conservation treatments. Soluble salts cause efflorescences, subflorescences or cryptoflorescences when they crystallise on or close to the surface of the stone or in its interior. Salts can also accumulate on the exterior in the form of a crust or surface deposit, more or less compacted. Furthermore, the pressure exerted by the crystallisation of soluble salts in pores and microfissures in the rock can cause disruption, especially in materials with and abundance of micropores, giving rise to different forms of physico-chemical deterioration (notably honeycomb structure and sandy disaggregation) (Valdeón et al., 1985; Binda and Baronio, 1987).

\section{Atmospheric pollutants}

The aggresiveness of water as an agent of chemical alteration can be enhanced by the presence of atmospheric pollutants (Arnáiz and Vale, 1977; Benarie, 1985; Roswall, 1988). Among the pollutants which can affect, directly or indirectly, the durability of building stones, are carbon and nitrogen oxides and sulphur compounds, many of which are of anthropogenic origin (mainly derived from the combustion of fossil fuels). In the presence of moisture, these substances attack rock components, producing soluble salts, the harmful effects of which have already been mentioned. It is in urban and industrial areas, in which the highest levels of pollution have been reached in recent decades, that the deterioration of rock materials has been found to be most accelerated, though the effects of these substances can also extend into rural areas in the form of acid rain.

\section{Other agents and mechanisms}

In addition to those already described, building stones are exposed to other mechanisms of deterioration. The biological action of certain living organisms (bacteria, algae, fungi, lichens, etc), by means, above all, of the chemical substances they produce (e. g. organic acids), sometimes assists in the physico-chemical deterioration of rock materials (Valentín, 1990). The presence of 
(Valentín, 1990). No siempre, sin embargo, la presencia de organismos en la piedra debe suponer necesariamente un daño para la misma, al margen de apreciaciones estéticas (Krumbein, 1988). Hay que mencionar, asimismo, la posible incidencia, a la hora de promover o facilitar el deterioro de una piedra, de agentes y mecanismos tales como: la erosión eólica (abrasión), los ciclos térmicos, el relajamiento de tensiones, las sobrecargas externas, las vibraciones...sin olvidar los efectos de la acción antrópica (De Angelis D'Ossat, 1982).

En cualquier caso, la mayor o menor susceptibilidad al deterioro de una piedra de construcción depende no sólo de las características intrínsecas de material (mineralogía, textura, porosidad, etc), a las que se ha hecho ya referencia, sino también de los agentes y factores extrínsecos actuantes en cada caso. Así, por ejemplo, un mismo material pétreo se comporta, de hecho, en el mismo período de tiempo, de forma distinta en función de su ubicación en el edificio y de las condiciones microambientales del lugar.

\section{CONSERVACION}

La conservación de la piedra de los edificios es conveniente enfocarla desde dos perspectivas: una, de carácter preventivo, en la que se contempla la intervención en el entorno más que directamente sobre la piedra; otra es la intervención en la piedra con el planteamiento de las fases de limpieza, consolidación, protección, sustitución y reposición como posibles etapas a abordar, según el tipo y grado de deterioro.

En la práctica, cuando se acomete un trabajo de conservación, deberían contemplarse ambas perspectivas ya que, la evolución futura de la piedra tratada, después de llevar a cabo cualquiera de las etapas de conservación antes mencionadas, es mucho más positiva si se minimiza o controla la acción de los factores exógenos.

Desde el punto de vista científico, las investigaciones que se vienen desarrollando en el campo de la conservación de la piedra monumental, están encaminadas a profundizar en los aspectos mencionados.

Así, se encuentran numerosos publicaciones en las que se analizan los factores ambientales y su incidencia en el deterioro de la piedra monumental. Algunos son tratados de carácter general, tales como: Domaslowski et al., 1982; Amoroso y Fassina, 1983, etc. Otros tienen carácter más específico: Bernardi et al., 1985; Dassu y Piazzoli, 1985; Delgado Rodrigues y Gil Saravia, 1985; Vázquez ot al., 1987; Lipfert 1989, De Tomassi y Laurenzi-Tabasso, 1989, etc. organisms in building stone does not always cause damage, however, apart from aesthetic considerations (Krumbein, 1988). Other agents which can promote or facilitate deterioration include: aeolian erosion (abrasion), thermal cycling, the release of internal stress, external loading, vibration and, not to be forgotten, human activity (De Angelis D'Ossat, 1982).

In all cases, the greater or lesser susceptibility of building stone to deterioration depends not only upon the intrinsic characteristics of the rock itself (mineraligy, texture, porosity, etc), which have already been referred to, but also upon external agents and factors that vary from case to case. Thus, over a given period of time, the same rock material behaves differently according, for example, to its position in a building and the environmental conditions encountered in that position.

\section{CONSERVATION}

In the conservation of stone in buildings, it is convenient to focus upon two different aspects of the work: firstly, the prevention of damage, in which measures are taken more in the environment than on the stone itself; and, secondly, remedial action on the stone, in which cleaning, consolidation, pretection, substitution and replacement are the possible steps to be undertaken, according to the type and degree of deterioration.

In practice, when conservation work is undertaken, both preventive and remedial measures must be considered, as the future durability of the stone after carrying out conservation work is much better assured if the effects of external factors are minimised or controlled.

Regarding the scientific work being carried out in the field of conservation of monumental stone, many investigations, are currently underway, each studying various different aspects in depth.

Many publications have analyzed environmental factors and their role in the deterioration of monumental stone. Some are of a general nature: Domaslowki et al., 1982; Amoroso and Fassina, 1983, etc. Others deal with more specific aspects: Bernardi et al., 1985; Dassu and Piazoli, 1985; Delgado Rodrigues and Gil Saravia, 1985, Vázquez et al., 1987; Lipfert, 1989; De Tomassi and Laurenzi-Tabasso, 1989, etc. 
También es relativamente amplia la bibliografía referida a la incidencia de la contaminación ambiental en el deterioro de la piedra de edificación: Furlan y Girardet, 1983; Ball y Hume, 1983, Esbert y Marcos, 1983 y 1984; Williams, 1985; Heath, 1986; Jaynes y Cooke, 1987, Everett et al., 1989 , etc.

En cuanto a las etapas de tratamiento propiamente dichas, que conllevan la intervención en la piedra, deben plantearse considerando que ésta, como material de edificación, forma parte de una fábrica y cada uno de sus sillares está unido a los vecinos por un mortero o material aglomerante. Así pues es necesario tener un conocimiento previo de una serie de aspectos relacionados con la piedra, con los morteros de unión y con la fábrica de la cual son parte integrante. En este sentido, los conocimientos sobre las características petrofísicas de los materiales sobre los que se va a intervenir, del tipo y grado de deterioro, de la naturaleza y características físico-químicas de los productos de alteración, fundamentalmente de las sales solubles, la incidencia del biodeterioro, etc, resultan imprescindibles.

Así mismo deben tenerse en cuenta las características de la edificación que han influido en el deterioro de los sillares y los morteros: problemas de freáticos, distribución de humedades en los muros del edificio, etc.; también las lesiones de tipo estructural: fisuras generadas por distribución anómala de cargas, anclajes, etc., sin olvidar los distintos acabados de cantería, dados habitualmente a la superficie de los sillares, y la colocación de éstos en el edificio. Todos estos aspectos, que forman parte de la llamada fase de Diagnóstico, son fundamentales tanto para decidir qué etapas de conservación deberán llevarse a cabo (sustitución, tratamiento, reintegración), como qué procedimientos, métodos o productos pueden resultar más idóneos para el tratamiento de la piedra alterada.

La limpieza de una obra hecha en piedra, suele llevarse a cabo para suprimir costras, depósitos y pátinas perjudiciales para la misma. Previamente a la aplicación de cualquier procedimiento de limpieza, deben hacerse un serie de consideraciones, en relación con el valor artístico del objeto y con la naturaleza de la piedra y de los productos que se quieren eliminar, con el fin de elegir el más adecuado. Los diversos métodos de limpieza suelen estar basados en la aplicación de agua, de procedimientos mecánicos, de disolventes químicos, de disolventes orgánicos, en el uso de arcillas especiales, del calor, de los ultrasonidos, etc. En Lazzarini, 1981, y en Lazzarini y Laurenzi Tabasso, 1986, se encuentran descritos estos diversos métodos.
The bibliography covering specific aspects of environmental pollution is also quite extensive: Furlan and Girardet, 1983; Ball and Hume, 1983; Esbert and Marcos, 1983 and 1984; Williams, 1985; Heath, 1986; Jaynes and Cooke, 1987; Everett et al., 1989, etc...

With regard to conservation measures which involve remedial action on the rock itself, it must be recognised that the stone, as a building material, forms only part of a structure, each block being fixed to its neighbours by a mortar or cement. There must, therefore, be an integrated approach to treating the stone, the mortar and the entire building of which they form part. To this end, an understanding of the petrophysical characteristics of the materials to be treated, of the type and degree of deterioration, of the nature and physico-chemical characteristics of the alteration products, of the fundamental role of soluble salts, and of the incidence of biodeterioration etc, is essential.

In the same way, the characteristics of the building itself that have influence the deterioration of blocks and mortars must be taken into account: problems related to the water table, the distribution of moisture in the walls of the building etc.; structural faults, including cracks caused by uneven distribution of loads, tie bars etc.; not forgetting the different types of quarry finish applied to block surfaces and the location of the blocks in the building. All of these aspects, which form part of the 'diagnostic' phase of conservation, are essential both in deciding which stages of conservation work should be applied (substitution, treatment or replacement), and which procedures, methods or products are most suitable for the treatment of the altered stone.

Cleaning of a stone work is normally undertaken in order to remove damaging crusts, deposits and patinas. Prior to any cleaning procedure, and in order to select the most appropriate method, a number of factors must be considered in relation to the artistic value of the object, the nature of the stone and the type of alteration products to be removed. The different cleaning techniques available tend to be based upon the application of water, mechanical procedures, chemical solvents, organic solvents, special clays, heat, ultrasonic techniques, etc... These methods are described in Lazzarini, 1981, and Lazzarini and Laurenzi Tabasso, 1986. 
La consolidación consiste en aplicar a la piedra un producto que mejora la cohesión entre sus componentes minerales lo que, a su vez, conlleva un aumento de la resistencia mecánica de la misma. Al mismo tiempo se mejora la adhesión entre la parte más deteriorada -exterior-y la parte más sana -interior- de la piedra. La consecuencia más inmediata de la consolidación es el cambio de la porosidad del material pétreo, por la entrada, en los espacios vacíos, de un producto nuevo. El cómo este producto rellenará dichos espacios, y cuál será la nueva porosidad de la piedra tratada y su nueva distribución porométrica, son aspectos, en principio desconocidos. Sin embargo, su conocimiento es de capital importancia para tener una idea del grado de idoneidad del tratamiento, ya que las características antes citadas son las que condicionan la captación y transferencia de humedad por el interior del sistema piedratratamiento.

Existen en el mercado productos consolidantes de diferente naturaleza química, tanto inorgánicos como orgánicos. Entre los primeros cabe mencionar la cal y el bicarbonato de cal, el hidróxido de bario, y el aluminato de potasio. Entre los segundos podrían citarse los diversos tipos de resinas acrílicas, epoxídicas, los poliuretanos, resinas de poliester, etc., así como los productos a base de silicio: silicatos, fluosilicatos, alquil-alcoxi-silanos, polisiloxanos, etc.

La protección de la piedra, tal como se concibe en la actualidad, tiene la finalidad de conferir a la superficie de la misma, expuesta a la intemperie, un carácter hidrorrepelente. La protección se lleva a cabo aplicando sustancias químicas que actúan de pantalla entre la piedra y el ambiente. Al paliar la acción del agua, indirectamente se reducen los fenómenos de alteración ligados a su presencia como disolución, transporte y cristalización de sales, fenómenos de hielo-deshielo, acción de los contaminantes atmosféricos, etc.

Los productos protectores más habitualmente utilizados suelen tener diversa naturaleza química: polisiloxanos, alquil-alcoxi-silanos, polímeros fluorados, mezclas acrílicas fluoradas, mezclas acrílicas silicónicas, poliuretanos, cera microcristalina, etc.

Numerosas empresas químicas fabrican productos concebidos para la consolidación y protección de la piedra, entre ellas pueden citarse: Rhom \& Haas, I.C.I., Du Pont, Stac, Ciba Geigy, Rhône-Poulenc, Wacker Chemie, Th. Goldschmidt, Dow Chemical, General Electric, Bayer, etc. Algunos de estos productos están diseñados para ejercer simultáneamente una acción consolidante e hidrofugante.

La experiencia práctica aconseja que, antes de la aplicación de cualquier producto de tratamiento a
Consolidation consists of the application of a material which improves the cohesion between the mineral components and, in turn, increases the mechanical resistance of the rock. At the same time, the adhesion of the most deteriorated exterior part of the rock to the less altered interior is improved. The most immediate result of consolidation is a change in the porosity of the stone by the entry into empty pore spaces of the consolidant. How the cosolidant fills the pore spaces, creating the new porosity and new porometric distribution of the treated stone, are poorly understood. Their understanding, however, is of great importance in determining the suitability of the treatment, since the results determine the uptake and transfer of moisture through the interior of the stone-treatment system.

Consolidants of different chemical nature are available, both inorganic and organic. Among inorganic consolidants are lime, bicarbonate of lime, barium hydroxide and potassium aluminate. Those of an organic nature include various resins: acrylic, epoxy, poliurethane, polyester, etc., and silicon-based products: silicates, fluosilicates, alkyl-alkoxy-silanes, polysiloxanes, etc...

Protection of building stone confers to the surface of the rock, exposed to the action of weathering agents, hydrorepellent properties by the application of chemical substances which act as a screen between the rock and the environment. By minimising the action of water, the effects of alteration phenomena associated with water ingress, such as dissolution, transport and crystallisation of salts, freeze-thaw phenomena, the action of atmospheric pollutants, etc, are also reduced.

The more usual protective products are chemically diverse: polysiloxanes, alkyl-alkoxy-silanes, fluorate polymers, fluoro-acrylic compounds, acrylic siliconic compounds, poliuretanes, microcrystalline wax, etc.

Numerous chemical companies manufacture products designed for the consolidation and protection of building stone, including: Rhom and Haas, I.C.I., Du Pont, Stac, Ciba Geigy, RhônePoulenc, Wacker Chemie, Th. Goldschmidt, Dow Chemical, General Electric, Bayer, etc. Some of these products have at the same time, a consolidant an hydrofuguing action.

Before the application of any treatment product to a building, experiments must be carried out in the 
una determinada piedra de edificación, es necesario llevar a cabo algunas experiencias en el laboratorio y, a ser posible, también en zonas restringidas del propio edificio, con el fin de tener una aproximación sobre el futuro comportamiento del sistema piedra-tratamiento.

El modo de aplicación de los productos de tratamiento, así como la preparación previa de la piedra a tratar, eliminando sales solubles, pátinas nocivas, etc., son factores que condicionan el grado de eficacia de los tratamientos.

Una idea del grado de dicha eficacia puede tenerse estudiando, en el laboratorio, la variación de determinadas propiedades físicas (p. ej.: succión capilar, absorción y desorción de agua, permeabilidad al vapor de agua, hinchamiento, etc.) antes y después de aplicar los tratamientos.

En la bibliografía se encuentra un gran número de investigaciones que se ocupan del estudio de los cambios de las propiedades físicas y de la durabilidad de los sistemas piedra-tratamiento. Podrían citarse, entre otros, los trabajos de Lewin y Baer, 1974; Rossi-Manaresi y Ghezzo, 1978; Grissom y Weiss, 1981; Charola et al., 1985; Laurenzi-Tabasso y Santamaría, 1985; Grossi, 1986; Esbert et al., 1987; Domaslowski y Lukaszewics, 1988; Alessandrini et al., 1988; Esbert et al., 1990; etc.

Finalmente, la evolución posterior de los tratamientos de conservación en el monumento, debe ser controlada mediante el seguimiento periódico, basado en la observación y medida "in situ", de ciertos parámetros relacionados fundamentalmente con la transferencia de humedad por el interior de la piedra.

\section{AGRADECIMIENTOS}

Este trabajo sintetiza el desarrollo de una línea de investigación, llevada a cabo en el Area de Petrología y Geoquímica del Dpto. de Geología de la Universidad de Oviedo, a lo largo de los últimos años, por varios de sus miembros.

En este sentido nuestro agradecimiento a los Drs. Fco. Javier Alonso, Luis Miguel Suárez del Río, Angel Rodríguez Rey, Lope Calleja, Vicente Gómez, y Luis Valdeón. También a las doctorandas Dña. Rosa M. Marcos, Dña. Carlota María Grossi y Dña. Beatriz Menéndez.

Finalmente nuestro agradecimiento a la Comisión Interministerial de Ciencia y Tecnología: Proyecto n. ${ }^{\circ} 485 / 88$. laboratory and, if possible, in the building itself, or in restricted parts of its, in order to obtain an understanding of the future behaviour of the stone-treatment system.

The effectiveness of particular treatment methods depends upon the mode of application of the products employed, and the initial preparation of the stone, removing soluble salts, patinas, etc.

An indication of the effectiveness of treatment methods can be obtained by studying, in the laboratory, variations in measured physical properties (e.g. capillary suction, absortion and desorption of water, permeability to water vapour swelling, etc.) before and after the application of treatment products.

In the bibliography, numerous investigations are described in which the changes in physical properties and durability of stone-treatment systems have been studied. Among those which can be cited are the works of Lewin and Baer, 1974; Rossi-Manaresi and Ghezzo, 1978; Grissom and Weiss, 1981; Charola et al., 1985; Laurenzi-Tabasso and Santamaría, 1985; Grossi, 1986; Esbert et al., 1987; Domaslowski and Lukaszewics, 1988; Alessandrini et al., 1988; Esbert et al., 1990; etc.

Finally, the evolution of conservation treatments on the monument itself during the period following their application must be understood, by observation and measurement "in situ" of certain parameters related essentially to the transfer of moisture through the interior of the stone.

\section{ACKNOWLEDGEMENTS}

This paper reviews the development during recent years of a line of investigation in the Petrology and Geochemistry Section of the Department of Geology, University of Oviedo, to which a number of researchers have contributed.

The authors wish to thank Drs. F. Javier Alonso, Luis Miguel Suárez del Río, Angel Rodríguez Rey, Lope Calleja, Vicente Gómez, and Luis Valdeón for their contribution to the research. Thanks are also extended to graduated students Dña. Rosa M. Marcos, Dña. Carlota María Grossi, and Dña. Beatriz Menéndez.

The support of the Comision Interministerial de Ciencia y Tecnología, Project 485/88, is also gratefully acknowledged. 


\section{BIBLIOGRAFIA}

La siguiente lista de referencias bibliográficas, citadas en el texto, es sólo una selección orientativa de la abundante literatura científica sobre el tema.

ALESSANDRINI; BONECCHI, R.; BIOGLIA, E.; BUGINI, R.; NEPOTTI, R. y PERUTTI, R. (1988): "Palazzo dei Giureconsulti (MilanItaly). Identification of stone materials. Causes of decay and conservation methods". VIth International Congress on Deterioration and Conservation of Stone, Torun (Polonia), pp. 330-340.

ALONSO, F. J.; ESBERT, R. M. y ORDAZ, J. (1987): "Caracterización del sistema poroso de calizas y dolomías". Boletín Geológico y Minero. T. XCVIII-II, pp. 226-237.

AMOROSO, G. G. y FASSINA, V. (1983): "Stone decay and conservation", Material Science Monographs, 11. Elsevier Ed. Amsterdam, $453 \mathrm{p}$.

ARNAIZ, M. y MARTIN A. (1977): "Alteración de materiales pétreos de obras monumentales. Acción de la contaminación ambiental". Monografías del Inst. Eduardo Torroja de la Construcción y del Cemento, C.S.I.C., Madrid, n. ${ }^{\circ}$ 340, 62 p.

ARNOLD, A. y ZEHNDER, K. (1989): "Soluble salts and stone decay." The Conservation of Monuments in the Mediterranean Basin. Proceed. of the 1st. Int. Symp., Bari, pp. 31-58.

ASTM (1988): "Annual Book of ASTM Standars". Section 4, Construction. Volumen 04.08. ASTM (Ed.) 953 p.

BALL, D. J. y HUME, R. (1983): "The relative importance of vehicular and domestic emissions of dark smoke in Greater London in the mid 1970s, the significance of smoke shade measurements and an explanation of the relationship of smoke shade to gravimetric measurements of particulates". Atmospheric Environment, 17, pp. 169-181.

BENARIE, M. (1985): "Research directions on the environmental deterioration and on the conservation of historic buildings and monuments". En: The Effects of Air Pollution on Historic Buildings and Monuments. Commission of the European Communities, Environment Research Programme, Padua, pp. II/1-33.

BERNARDI, A.; CAMMUFFO, D.;DEL MONTE, M. and SABBIORI, G. (1985): "Microclimate and weathering of an Historical Building: The Ducal Palace in Urbino". The Science of Total Environment, 46, pp. 246-260.

BINDA, L., BARONIO, G. (1987): "Mechanisms of masonry decay due to salt crystallization". Durability of Building Materials, Vol. 4, n. 3, pp. 227-240.

CHAROLA, A. E.; LAURENZI-TABASSO, M. y SANTAMARIA, U. (1985): "The effect of water on the hydrophobic properties of an acrylic resin". Vth International Congress on Deterioration and Conservation of Stone, Lausanne, pp. 739-747.

CNR-ICR (1985): "Assorbimento d'acqua per capillaritá. Coefficiente di assorbimento capillare". Doc. Normal: 11/85. Roma, 7 p.

CNR-ICR (1985): "Permeabilitá al vapor d'acqua". Doc. Normal: 21/85, Roma, 5 p.

DASSU, G. and PIAZZOLI, G. (1985): "The Certosa of Pavia: Climatic and Microclimatic Data". Vth International Congress on Deterioration and Conservation of Stone. Lausanne, pp. 453-465.

DE ANGELIS D'OSSAT, G. (1982): "Guide to the methodical study of monuments and causes of their deterioration". ICCROM, Roma, $46 \mathrm{p}$.

DELGADO RODRIGUES, J. and GIL SARAVIA, J. A. (1985): "Experimental and Theoretical Approach to the study of the Mechanism of Wind Erosion of Stone in Monuments". Vth International Congress on Deterioration and Conservation of Stone. Lausanne, 167175.

DE TOMASSI, G. and LAURENZI-TABASSO, M. (1989): "La Cattedrale di Trani: influenza di condizione ambientali controllate sul degrado del paramento interno". The Conservation of Monuments in the Mediterranean Basin. Bari, pp. 397-406.

DOMASLOWSKI, W.; KOZANECKA, J. K.; RUDY, M.; SOBKOWIAK, D. y SOLDENHOFF, B. (1982): "La conservation préventive de la pierre". Musées et Monuments XVIII, UNESCO, $158 \mathrm{p}$.

DOMASLOWSKI, W. y LUKASZEWICS, J. W. (1988): "Possibilities of silica application in consolidation of stone monuments". VIth Congress on Deterioration and Conservation of Stone, Torun (Polonia), pp. 563-576.

ESBERT R. M. y MARCOS R. M. (1983): "Las piedras de la Catedral de Oviedo y su deterioración". Public. Colegio Oficial de Aparejadores y Arquitectos Técnicos de Asturias. Gráficas Summa, Oviedo, 143 p.

ESBERT, R. M. y MARCOS R. M. (1984): "Incidencia de los factores ambientales en los mecanismos de alteración de las piedras de la catedral de Oviedo". I Congreso Nacional de Geología. Segovia, Tomo I. pp.635-809. 
ESBERT, R. M. y ORDAZ J. (1985): "Alteración y alterabilidad de las piedras de construcción: criterios petrofísicos y ensayos de laboratorio". I Congreso de Patología en la Edificación, C.O.A.C., Barcelona, 15 p.

ESBERT, R. M.; GROSSI, C. M. y MARCOS, R. M. (1987): "Estudios experimentales sobre la consolidación y la protección de los materiales calcáreos de la Catedral de Oviedo. 1." Parten. Materiales de Construcción, Vol. 37, 206, pp. 17-25.

ESBERT, R. M.; MARCOS, R. M.; ORDAZ, J.; MONTOTO, M.; SUAREZ DEL RIO, L. M.; RUIZ DE ARGANDOÑA, V. G.; CALLEJA, L.; ALONSO, F. J.; RODRIGUEZ-REY A. (1989): "Petrografía, propiedades físicas y durabilidad de algunas rocas utilizadas en el patrimonio monumental del Catalunya, España". Materiales de Construcción. Vol. 39, n. ${ }^{\circ} 214$, pp. 37-47.

ESBERT, R. M.; GROSSI, C. M.; VALDEON, L.; ORDAZ, J.; ALONSO, F. J. y MARCOS, R. M. (1990): "Estudios de laboratorio sobre la conservación de la Catedral de Murcia". Materiales de Construcción. Vol. 40, n. ${ }^{\circ}$ 217, pp. 5-15.

EVERETT, L. H., (Chairman) (1989): "The effects of Acid Deposition on Buildings and Building Materials in the United Kingdom". Building Effects Review Group Report. Department of the Environment, 106 p.

FURLAN V. y GIRARDET, L. F. (1983): "Considerations on the rate of accumulation of sulphurous pollutants in exposed stones". Materials Science and Restoration International Conference. Esslingen, pp. 285-290.

GODDARD, E. N.; TRASK, P. D.; DE FORD, R. K.; ROVE, O. N.; SINGEWALD, J. T. y QUERBECK, R. M. (1979): "Rock-ColorChart". The Geological Society of America, Boulder, Co. U.S.A.

GRISSOM, C. A. y WEISS, N. R. (1981): "Akoxysilanes in the conservation of Art and Architecture". Art and Archaelogy Technical Abstracts, IIC, vol. 18; n. 1, pp. 150-200.

GROSSI, C. M. (1986): "Ensayos de tratamiento en materiales rocosos de la Catedral de Oviedo". Tesis de Licenciatura, Dpto. de Geología y Geoquímica. Universidad de Oviedo, 122 p.

HEATH, M. (1986): "Polluted rain falls in Spain". New Scientist, n. ${ }^{\circ} 1.526$, pp. 60-62.

ISRM (1979): "Commission on Standarization of Laboratory and Field Test". Int. J. Rock Mech. Min. Sci. \& Geomech. Abstr. Vol. $16,{ }^{\circ} 2, p p .143-156$

ISRM (1981): "Suggested methods for laboratory testing of angillaceous swelling rocks". International Journal of Rock Mechanics and Mining Sciences. Vol. 26. n. ${ }^{\circ}$, pp. 415-427.

JAYNES, S. M. y COOKE R. U. (1987): "Stone weathering in southeast England". Atmospheric Environment, 21, pp. 1.601-1.622.

KRUMBEIN, W. E. (1988): "Biotransformations in monuments - A sociobiological study". Durability of Building Materials, Vol. 5, pp. 359-382.

LAURENZI-TABASSO, M. y SANTAMARIA, U. (1985): "Consolidant and protective effects of different products on Lecce Limestone". Vth International Congress on Deterioration and Conservation of Stone, Lausanne, pp. 697-707.

LAUTRIDOU, J. P. (1988): "Recent advances in cryogenic weathering". En: Advances in Periglacial Geomorphology (M. J. Clark, Ed.), John Wiley and Sons, pp. 33-47.

LAZZARINI, L. (1981): "La pulitura dei materiali lapidei da costruzione e scultura". CEDAM. Edit. Dott. Antonio Milani, Padova, 138 p.

LAZZARINI, L. y LAURENZI-TABASSO, M. (1986): "II Restauro della piedra". CEDAM. Edit. Dott. Antonio Milani, Padova, 320 p.

LIPFERT, F. (1989): "Atmospheric Damage to Calcareous Stones: Comparison and Reconciliation of Recent Experimental Findings". Atmospheric Environment, Vol. 23, pp. 415-425.

LEWIN, S. Z. y BAER, N. S. (1974): "Rationale of the barium hydroxide-urea treatment of decayed stone". Studies in Conservation, vol. 19, pp. 24-35.

MONTOTO, M. (1983): "Petrophysics: The petrographic interpretation of the physical properties of rocks". 5th Congress of the Int. Soc. for Rock Mechanics, Melbourne (Australia), Vol. B, pp. 93-98.

ORDAZ, J. y ESBERT, R. M. (1988): "Glosario de términos relacionados con el deterioro de las piedras de construcción". Materiales de Construcción. Vol. 38, 209, pp. 39-45.

PRESS, F. y SIEVER, R. (1985): "Weathering: The decomposition of rocks". En: Earth (Chap. 5), pp. 101-124.

ROSSI-MANARESI, R. y GHEZZO, C. (1978): "The biocalcarenite of the Agrigento. Greek Temples: causes of the alteration and effectiveness of conservation treatments". Int. Symp. on Deterioration and Protection of Stone Monuments, París, 7.9, 31 p. 
ROSVALL, J. (1988): "Air pollution and conservation". Durability of Building Materials, Vol. 5, n. 3-4, pp. 209-237.

STAMBOLOV, T. y VAN ASPEREN DE BOER, J. R. J. (1976): "The deterioration and conservation of porous building materials. A review of the literature". ICCROM, Roma, $86 \mathrm{p}$.

TORRACA, G. (1982): "Porous building materials: Materials science for architectural conservation". Roma, $141 \mathrm{p}$.

UNE (1985): "Catálogo de Normas UNE 1985". Instituto Español de Normalización (CSIC, Ed.) 417 p.

VALDEON, L.; ESBERT, R. M. y MARCOS, R. M. (1985): "La alveolización y otras formas de alteración desarrolladas sobre las areniscas del Palacio de Revillagigedo de Gijón". Materiales de Construcción, 35, pp. 41-48.

VALENTIN, N. (1990): "Biodeterioro en rocas monumentales". (Documento interno). ICRBC, Ministerio de Cultura, Madrid, 26 p.

VAZQUEZ, M. A.; GALAN, E. y ALCALDE, M. (1987): "The Cathedral of Cádiz, Spain: deterioration state". In the Vith Meeting of the European Clay Groups, Cádiz, pp. 49-52.

WARDLAW, N. C. y TAYLOR, P. P. (1976): "Mercury capillary pressure curves and the interpretation of pores structure and capillary behaviour in reservoir rocks". Bull. Canad. Petrol. Geol. 24 (2), pp. 225-262.

WILLIAMS, H. (1985): "Identification and assessment of materials damage to buildings and historic monuments by air pollution". En: The Effects of Air Pollution on Historic Buildings and Monuments. Commission of the European Communities, Environment Research Programme, Padue, pp. III/17-68.

WINKLER, E. M. (1987): "Weathering and weathering rates of natural stone". Environmental Geology and Water Sciences, Vol. 9 , n. 2, pp. 85-92.

\section{publicación del. ICCET/CSIC}

\section{ACUEDUCTOS ROMANOS EN ESPAÑA \\ Carlos Fernández Casado \\ Prof. Dr. Ing. de Caminos, Canales y Puertos}

Esta publicación se compone de una serie de articulos, publicados en la Revista "Informes de la Construcción", en los cuales se hace un análisis de los acueductos romanos que existen en España y el balance de las condiciones de conservación en que se encuentra cada uno de ellos, incluyendo referencias históricas y literarias. Se ha ilustrado con la reproducción de la valiosa documentación gráfica que posee el prestigioso autor.

Un volumen encuadernado en couché, a dos colores, de $21 \times 27$ centimetros, compuesto de 238 páginas, numerosos grabados, dibujos, fotos en blanco y negro y figuras de línea.

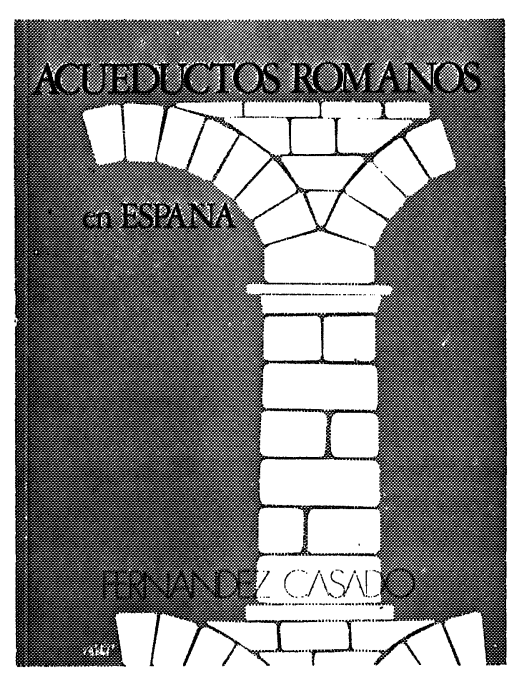

